Holovan, O., Oliynyk, O. and Markova, S. (2021), “Application of modern methods of service quality assessment for diagnostics of higher education institution corporate culture", Management and entrepreneurship: trends of development, 1(15), pp. 65-79. Available at: https://doi.org/10.26661/2522-1566/2021-1/15-04

MANAGEMENT

\section{RECEIVED:}

12 January 2021

ACCEPTED:

12 February 2021

RELEASED:

20 March 2021
UDC 330.341.1

DOI 10.26661/2522-1566/2021-1/15-04

\title{
APPLICATION OF MODERN METHODS OF SERVICE QUALITY ASSESSMENT FOR DIAGNOSTICS OF HIGHER EDUCATION INSTITUTION CORPORATE CULTURE
}

\author{
Olha Holovan \\ Zaporizhzhia National \\ University \\ Zaporizhzhia, Ukraine \\ ORCID: 0000-0002-9410-3830
}

\author{
Oleksandr Oliynyk* \\ Zaporizhzhia National \\ University \\ Zaporizhzhia, Ukraine \\ ORCID: 0000-0003-0511-7681
}

\author{
Svitlana Markova \\ Zaporizhzhia National \\ University \\ Zaporizhzhia, Ukraine \\ ORCID: 0000-0003-0675-0235
}

*Corresponding author email: a.n.oleynick@gmail.com

Abstract. The sphere of education is one of the domestic economy development drivers. Its development is impossible without the formation of a stable and adaptive organizational culture of educational institutions. To form the corporate culture of a higher education institution, a necessary step is to diagnose its current state. The purpose of this study is to adapt the modern SERVQUAL method of assessing the service quality to diagnose the state of higher education institution corporate culture. Methodology: In the study the student's expectations and their perception of the received educational service quality according to the indicators of the adapted SERVQUAL method. The application of the SERVQUAL method to diagnose the level of higher education institution corporate culture has revealed existing problems and appropriate areas for improvement. The research findings show that among the main problems are the lack of free and quality access to Wi-Fi at the university; provision of bases of practices and insufficient level of cooperation with potential employers to provide opportunities for further employment after graduation; understanding of the problems and difficulties faced by students during their studies by the teaching staff. As measures to help improve the higher education institution corporate culture, it has been proposed: to hold various competitions between departments, teachers and students; organization of joint cultural and educational events for students and teachers of the faculty; development of programs of financial stimulation of scientific and creative activity of students.

Keywords: educational services, corporate culture, higher education institution, service quality, quality diagnostics.

JEL Classification: M14, L15, I25.

\section{INTRODUCTION}

The service sector is one of the key structural elements of the domestic economy. In the structure of domestic GDP, the share of services is constantly growing: there are new types of services, as well as organizations that provide them. This leads to increased competition in this area and makes it necessary to ensure of appropriate quality of services provided to consumers. 
Organizations operating in the service sector are faced with the need to constantly measure the quality level of services offered.

\section{LITERATURE REVIEW}

Methods for assessing the service quality have been studied by leading economists. The most common tool for assessing the service quality is the model of service quality or the model of differences in service quality, proposed by W. Zeitaml, A. Parasuraman and L. Berry (1985). This method is widely used in applied research. Yu. V. Demyanenko uses the model to assess the level of social capital of enterprises in the service sector; Stadnik VG applies this model to assess the quality system of the freight forwarding company, .Kostrubska, V.S. Kovalchuk evaluate the quality of banking services.

The works of R.A Logua (2012) and N.I. Ivashkova (2015) are devoted to the improvement and expansion of analytical capabilities of this model. The practical aspects of using the model are studied in the works of V.E. Novatorova and V.D. Novitskaya (2012) and others. A.V. Bazilyuk, I.O. Khomenko (2013) extended the application of the SERVQUAL method to assess the logistics services quality. O.O. Golovan, O.M. Oliynyk, S.V. Markova, A.I. Kornienko (2016) determine the adaptation directions of the customer loyalty assessment mechanism for the supermarket chain Silpo in the context of ensuring its market position and propose the ways to improve the SERVQUAL method, which make it possible to apply it not only to assess the bank customers loyalty, but also to other sectors, in particular for the retail. V.I. Okhota, V.Ya. Brych (2020) systematize and characterize the main indicators of the tourism industry services quality at the methodological and empirical levels.

Despite the significant theoretical and methodological development of the service quality assessment problem, the definition of quality criteria that affect the customer's choice service sector organizations, customer service quality assessment and competitiveness of companies in this sector remain insufficiently studied, particularly in the sector of higher education.

The sphere of education is one of the domestic economy development drivers. Its development is impossible without the formation of a stable and adaptive organizational culture of educational institutions. In modern conditions, higher education institutions in order to ensure high competitiveness should create a positive image in the social environment, involving all entities that have their own interests in the education field.

The problem of forming corporate culture as a necessary condition for the development of an educational institution and a precondition for ensuring its competitiveness is relevant one for Ukrainian universities. Peculiarities of the educational institutions organizational culture have been studied in the works of L. Karamushka (2015), N. Nakonechna (2020), I. Blokhina (2012), T. Koycheva (2014), Zavats'ka N. Ye., Mitichkina O. O. (2013) and other scientists.

To form the corporate culture of a higher education institution, a necessary step is diagnostics of its current state. Therefore, there is a need to adapt the SERVQUAL method to assess the diagnostics of the service quality in the education sector and higher education institution corporate culture.

\section{PAPER OBJECTIVE}

The purpose of this study is to adapt the modern SERVQUAL method of assessing the service quality to diagnose the state of higher education institution corporate culture.

\section{METHODOLOGY}

To substantiate the theoretical positions and reasoning of the conclusions general scientific 
Holovan, O., Oliynyk, O. and Markova, S. (2021), “Application of modern methods of service quality assessment for diagnostics of higher education institution corporate culture", Management and entrepreneurship: trends of development, 1(15), pp. 65-79. Available at: https://doi.org/10.26661/2522-1566/2021-1/15-04

methods are used, including system, abstract-logical approach, as well as methods of formalization, analysis and synthesis of information, comparative analysis and expert assessments, graphical visualization of factual information.

\section{RESULT AND DISCUSSION}

The concept of higher education institution corporate culture is based on the definition of corporate culture of the enterprise / organization, taking into account the specifics of the educational institution, which is the implementation of the educational process aimed at training future professionals.

The most common definitions of corporate culture are shown in Figure 1.

a set of basic assumptions, values, priorities and norms that determine the work behavior

of employees, provide constructive interaction in the team and contribute to the

successful functioning of the organization in the external environment

a set of values, concepts and beliefs shared by all members of the organization, as well

as behavioral norms and artifacts created by the organization in the process of

overcoming internal and external obstacles to success and prosperity

a set of norms, values, traditions, views, which are often not subject to formulation and a priori are accepted and shared by all members of the team

a system of guiding beliefs, principles and technologies in the enterprise

a set of the most important assumptions accepted by members of the organization and

expressed in the values declared by the organization which set to people guidelines of

their behavior and actions.

Figure 1. Approaches to the definition of corporate culture,

Source: Modified after Hnezdilova, K. M. (2013).

Summarizing all approaches, we can assume that the corporate culture of a higher education institution is a set of norms, values and traditions shared by all persons involved in the activities of this institution, and on the basis of which the relationship between all participants in the educational process is regulated, in particular, between teachers, faculty and students, faculty and administration.

The structure of the corporate culture of the organization may contain different components, considered at several levels. The model of $\mathrm{O}$. Andomin of higher educational institution corporate culture systematizes the elements of culture and means of its achievement (Table 1). 
Elements of $O$. Andomin model of higher education institution corporate culture

\begin{tabular}{|c|c|}
\hline Elements of corporate culture & Means of achievement \\
\hline \multirow{2}{*}{ Philosophy of a higher education institution } & University charter, \\
\hline & Code of Corporate Culture \\
\hline Organizational values & $\begin{array}{l}\text { Mission, policy of a higher education } \\
\text { institution }\end{array}$ \\
\hline Norms, rules of conduct & Rules of procedure \\
\hline History, traditions & Museum, veterans council, graduates club \\
\hline Psychological climate & Personal relationships between employees \\
\hline Corporate communications & $\begin{array}{l}\text { Access to information, means and methods of } \\
\text { communication }\end{array}$ \\
\hline Management style & $\begin{array}{l}\text { Organization and structure of a higher } \\
\text { education institution }\end{array}$ \\
\hline The image of a higher education institution & $\begin{array}{l}\text { The image of the university in the eyes of the } \\
\text { public, the design of the classrooms, attributes, } \\
\text { clothing of employees }\end{array}$ \\
\hline
\end{tabular}

Source: Modified after Hnezdilova, K. M. (2013).

At the present stage of reforming the higher education system in Ukraine, the modernization of higher education institutions requires a change in their corporate culture. An important step in forming the strategic goals of an educational institution is to assess the current state of its corporate culture, existing problems and possible consequences as a result of the implementation of changes. Thus, the study of higher education institution corporate culture pursues the goal of comparing the real and desired model (how staff and students would like to see their university).

The process of formation of higher education institution corporate culture can be represented in the form of the following stages (Figure 2), 
Holovan, O., Oliynyk, O. and Markova, S. (2021), “Application of modern methods of service quality assessment for diagnostics of higher education institution corporate culture", Management and entrepreneurship: trends of development, 1(15), pp. 65-79. Available at: https://doi.org/10.26661/2522-1566/2021-1/15-04

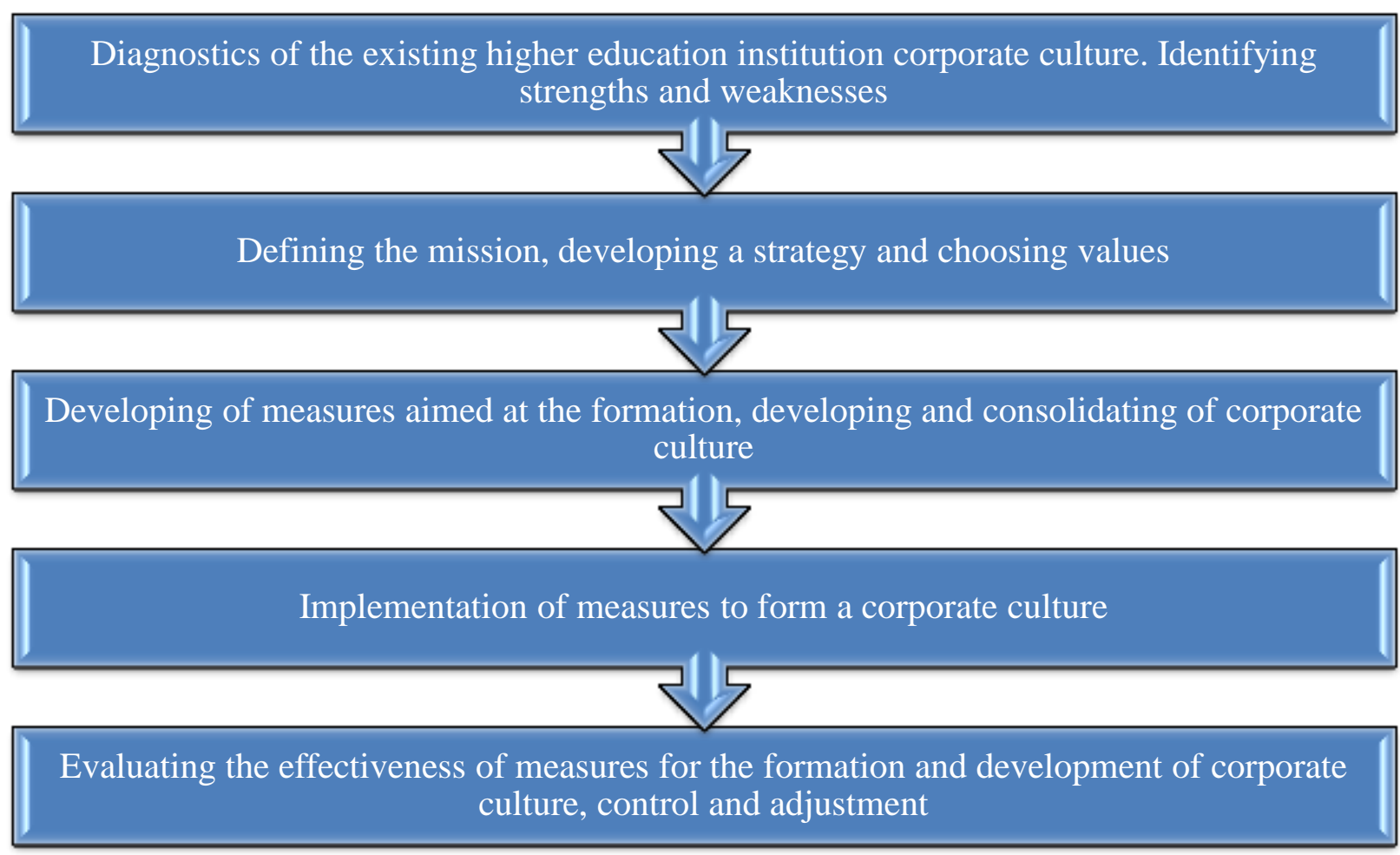

Figure 2. Stages of formation of higher education institution corporate culture

Source: Modified after Kubko, V. (2014).

Consider in more detail the first two stages of corporate culture.

\section{Diagnostics of the existing corporate culture.}

There are many tools for assessing and analyzing the corporate culture of organizations, but the OCAI method is more often used. This method is based on the theoretical model "Framework of competing values", developed by Cameron, K. S., Quinn, R. E. (2011). OCAI method makes it possible to diagnose the organization's culture for competing values at different stages of its development.

Under market conditions, higher education institutions in Ukraine are forced to form an entrepreneurial corporate culture in order to have financial stability and be relatively independent of public funding. When diagnosing the higher education institutions corporate culture, tools and approaches are used taking into account the specifics of their activities. Thus, in contrast to organizations engaged in production, trade or service activities, the main task of a higher education institution is to provide educational services, to meet human needs for professional education. A large number of professors and employees of the university take part in the providing of educational services, thanks to the coordinated activity of which the result is ensured.

A specific characteristic of the corporate culture of the university is also the uniformity of the professional activities of its employees. Unlike production organizations, where there is a division of labor, there is actually no professional division in higher education, as most employees are professors with the same professional responsibilities. The common tasks of professional activity should be perceived as an important factor in the formation of corporate culture of the university, which contributes to the unity of professors and their ability to form common values of corporate culture.

A specific feature of the corporate culture of a higher education institution is also its 
heterogeneity. The manifestation of heterogeneity is due to the fact that the administration of the institution is small in number compared to other organizations, but the formation of corporate culture is carried out by it. Thus, the university administration is interested in implementing measures to form a corporate culture, but professors may remain uninvolved in this process, as corporate relations between employees are formed naturally through business and interpersonal communication between them.

Due to the fierce competition between higher education institutions, universities are forced to actively fight for entrants, using methods and approaches that were not previously inherent in the field of education, but used by business organizations.

The SERVQUAL method is the most common tool for assessing the customer service quality in service organizations, which has proven its effectiveness. His students are clients for higher education institutions.

This technique involves the use of basic questionnaires "Expectations" and "Perceptions" to measure customer expectations and their perception of the service received quality. All questions in the questionnaires are grouped into blocks according to five quality indicators:

1) tangibles - all material objects used in the process of providing the service (equipment, appearance of classes and employees, printed materials, etc.);

2) reliability - the ability to provide the promised service;

3) responsiveness - the willingness of the organization's staff to help consumers provide services;

4) assurance - the competence of staff and hence customer confidence in the organization;

5) empathy - the degree of individual attention to customers, Toporova P. K. (2015).

Assessing customer satisfaction with the service quality helps the organization find out their expectations and requirements for providing high quality services and take into account all the mistakes and shortcomings in order to improve the level of service and, consequently, customer satisfaction.

The SERVQUAL method is a universal tool for assessing the service quality from the point of view of service consumers. Since higher education institutions provide educational services, we consider it appropriate to use this tool to assess student satisfaction with the education quality, which directly affects the image of higher education institution, which is an element of its corporate culture.

Indicators of the quality of the SERVQUAL method for the provision of educational services and their criteria are given in Table. 2.

To diagnose the image of a higher education institution using the SERVQUAL method, it is necessary to determine the expectations $E_{g_{k}}$ and perceptions $P_{g_{k}}$ of educational services quality by university students for each criterion $g_{k}$ of quality indicator $k(k=1,2, \ldots, 5)$ :

$$
E_{g_{k}}=\frac{1}{s} \sum_{i=1}^{s} \cdot m^{E}{ }_{g_{k}(i)}, \quad \quad P_{g_{k}}=\frac{1}{s} \sum_{i=1}^{S} \cdot m^{P} g_{k}(i)
$$

where $E_{g_{k}}-$ a level of student's expectations of the educational services quality;

$P_{g_{k}}$ - a level of student's perception of the educational services quality;

$i$ - number of the student who took part in the survey $(i=1, \ldots, s)$;

$s$ - the total number of students who participated in the survey;

$m^{E} g_{k}(i)$ - the expected assessment of the educational services quality, which is set by the student $i$ according to the criterion $g_{k}$;

$m^{P} g_{k}(i)$ - the perception assessment of the educational services quality, which is set by the student $i$ according to the criterion $g_{k}$;

$g_{k}-$ is the criterion of the $k$-th quality indicator $\left(g_{k}=1, \ldots, h_{k}\right)$. 
Holovan, O., Oliynyk, O. and Markova, S. (2021), “Application of modern methods of service quality assessment for diagnostics of higher education institution corporate culture", Management and entrepreneurship: trends of development, 1(15), pp. 65-79. Available at: https://doi.org/10.26661/2522-1566/2021-1/15-04

Table 2

Indicators of the educational services quality according to the SERVQUAL method

\begin{tabular}{|c|c|l|}
\hline № & Quality indicator & \multicolumn{1}{|c|}{ Criterion } \\
\hline 1 & Tangibles & $\begin{array}{l}\text { Appearance of buildings and campus; interior and equipment of classrooms; } \\
\text { free Wi-Fi on the territory of the university; modern computer classes and } \\
\text { multimedia classrooms; information support of the educational process. }\end{array}$ \\
\hline 2 & Reliability & $\begin{array}{l}\text { Fulfilling promises to provide educational services in a timely manner (even in } \\
\text { a pandemic); providing quality educational services for training specialists; } \\
\text { provision of bases of practices; cooperation with employers; employment } \\
\text { guarantee. }\end{array}$ \\
\hline 3 & Responsiveness & $\begin{array}{l}\text { Quick response to requests (requests) of students; trust and understanding on } \\
\text { the part of the teaching staff; willingness to help students in any situation; } \\
\text { active work of curators of academic groups, etc. }\end{array}$ \\
\hline 5 & Assurance & $\begin{array}{l}\text { High reputation of the university; availability of scientific schools; discipline } \\
\text { and politeness of employees, respect for students, etc. }\end{array}$ \\
\hline & Empathy & $\begin{array}{l}\text { Individual approach to each student, including in solving his problems (the } \\
\text { presence of academic debt, monthly tuition fees); focus on the needs of } \\
\text { students; convenient study schedule for students, etc. }\end{array}$ \\
\hline
\end{tabular}

Source: Own compilation.

Assessment of the expected quality $E_{k}$ and the perceived quality $P_{k}$ of educational service by university students for each quality indicator $k(k=1,2, \ldots, 5)$ is calculated by the formulas:

$$
E_{k}=\frac{1}{h_{k}} \sum_{g_{k}=1}^{h_{k}} \cdot E_{g_{k}}, \quad P_{k}=\frac{1}{h_{k}} \sum_{g_{k}=1}^{h_{k}} \cdot P_{g_{k}}
$$

where $h_{k}$ is the number of criteria for the $k$-th quality parameter.

Assessment of students' satisfaction with the quality of higher education institution is determined either by quality coefficients $Q_{g_{k}}$ for each individual criterion $g_{k}\left(g_{k}=1, \ldots, h_{k}\right)$ of quality indicator $k(k=1,2, \ldots, 5)$, or by generalized quality coefficients $Q_{k}$ for each $k$-th quality indicator according to the formulas, Lohua R. A. (2012):

$$
\begin{aligned}
& Q_{g_{k}}=P_{g_{k}}-E_{g_{k}}, \\
& Q_{k}=P_{k}-E_{k} .
\end{aligned}
$$

With the help of the education quality assessments obtained by the SERVQUAL method, specific recommendations are developed for improving the educational services quality, which affects the image of the university and its corporate culture. 
Confirmation of expectations regarding the educational services quality increases the level of student loyalty to the university, which, in turn, leads to an increase in the influx of applicants, as students who are satisfied with the education quality recommend the higher education institution to their relatives and friends; university graduates after some time recommend it to their children for professional education.

Evaluations of the educational services quality by students using the SERVQUAL method can be interpreted as follows:

1. If the quality coefficient for any quality indicator is zero $\left(Q_{g_{k}}=0\right.$ or $\left.Q_{k}=0\right)$, then the level of quality expectations and the level of the actual quality perception of this indicator coincide.

2. Negative values of quality coefficients $\left(Q_{g_{k}}<0\right.$ or $\left.Q_{k}<0\right)$ indicate that the level of the quality expectation of educational services exceeds the level of perception.

3. Positive values of quality coefficients $\left(Q_{g_{k}}>0\right.$ or $\left.Q_{k}>0\right)$ mean that the actual quality perception of study is higher than the level of expectation.

If the quality coefficients are zero or positive, they are considered successful; negative coefficients that approach zero are considered satisfactory, and negative coefficients that are significantly different from zero are considered unsatisfactory.

To assess the level of educational services quality according to the SERVQUAL method, along with absolute values, one can use relative values, taking as a basis for comparison, for example, the average level of service quality expectations or the maximum assessment of student expectations.

The calculation of the education quality coefficients in relation to student expectations and the ideal assessment of expectations can be done by the formulas, Toporova P. K. (2015):

$$
\begin{aligned}
& Q_{1}=\frac{E-P}{E} \cdot 100 \%, \\
& Q_{2}=\frac{Q_{\max }}{Q_{\max } \cdot 100 \%},
\end{aligned}
$$

where $Q_{1}$ - service quality coefficient relative to expectations;

$Q_{2}$ - service quality coefficient relative to the ideal;

$E$ - average assessment of the expected quality level for all indicators;

$P$ - the average assessment of the perceived quality level for all indicators;

$Q_{\max }$ - maximum assessment of education quality expectations.

The smaller the values of the coefficients $Q_{1}$ and $Q_{2}$, the higher the quality of educational services.

In this study the education quality at Zaporizhzhya National University was determined with the help of SERVQUAL method. The survey was conducted among the students of different courses of the Management Faculty.

Students were asked to assess the education quality according to 17 quality criteria, which are given in Table. 3, using a 7-point rating scale. 
Holovan, O., Oliynyk, O. and Markova, S. (2021), “Application of modern methods of service quality assessment for diagnostics of higher education institution corporate culture", Management and entrepreneurship: trends of development, 1(15), pp. 65-79. Available at: https://doi.org/10.26661/2522-1566/2021-1/15-04

Criteria for assessing the education quality in ZNU according to SERVQUAL method

\begin{tabular}{|c|c|}
\hline № & Criterion of educational service quality \\
\hline \multicolumn{2}{|r|}{ Tangibles } \\
\hline 1 & T1. Appearance of buildings and campus \\
\hline 2 & T2. Excellent interior and equipment for classrooms \\
\hline 3 & T3. Modern computer classrooms and multimedia classrooms \\
\hline 4 & T4. Free Wi-Fi at the university \\
\hline \multicolumn{2}{|r|}{ Reliability } \\
\hline 5 & H5. Fulfilling promises to provide educational services in a pandemic \\
\hline 6 & H6. Providing quality educational services \\
\hline 7 & H7. Provision of bases of practices, cooperation with employers \\
\hline 8 & H8. Employment guarantee \\
\hline \multicolumn{2}{|r|}{ Responsiveness } \\
\hline 9 & R9. Rapid response of the university administration to student requests \\
\hline 10 & R10. Trust and understanding on the part of the teaching staff \\
\hline 11 & R11. Willingness to help students in any situation \\
\hline \multicolumn{2}{|r|}{ Assurance } \\
\hline 12 & A12. High reputation of the university \\
\hline 13 & A13. Availability of scientific schools \\
\hline 14 & A14. Discipline and courtesy of employees, respect for students \\
\hline \multicolumn{2}{|r|}{ Empathy } \\
\hline 15 & $\begin{array}{l}\text { E15. Individual approach to each student in solving his problems with academic debt } \\
\text { or monthly tuition fees, etc. }\end{array}$ \\
\hline 16 & E16. Focus on the needs of students \\
\hline 17 & E17. Convenient study schedule for students \\
\hline
\end{tabular}

\section{Source: Own compilation.}

Using formulas (1) and (3), the assessment of the expected education quality and the assessment of the educational services perception, as well as the education quality coefficients in ZNU were determined. The results of the study are given in Table 4. 
Assessments of the education quality in ZNU according to SERVQUAL method

\begin{tabular}{|c|c|c|c|c|}
\hline Quality criterion & $\begin{array}{l}\text { Expectation } \\
E_{g_{k}}\end{array}$ & $\begin{array}{l}\text { Perception } \\
\quad P_{g_{k}}\end{array}$ & $\begin{array}{c}\text { Quality } \\
\text { coefficient } Q_{g_{k}}= \\
P_{g_{k}}-E_{g_{k}}\end{array}$ & Importance \\
\hline 1 & 2 & 3 & 4 & 5 \\
\hline \multicolumn{5}{|c|}{ Tangibles } \\
\hline $\begin{array}{l}\text { T1. Appearance of buildings } \\
\text { and campus }\end{array}$ & 6,87 & 6,75 & $-0,12$ & 6,52 \\
\hline $\begin{array}{l}\text { T2. Excellent interior and } \\
\text { equipment for classrooms }\end{array}$ & 6,48 & 4,56 & $-1,92$ & 6,65 \\
\hline $\begin{array}{l}\text { T3. Modern computer } \\
\text { classrooms and multimedia } \\
\text { classrooms }\end{array}$ & 6,74 & 5,22 & $-1,52$ & 6,87 \\
\hline $\begin{array}{l}\text { T4. Free Wi-Fi at the } \\
\text { university M4 }\end{array}$ & 6,35 & 4,28 & $-2,07$ & 6,91 \\
\hline \multicolumn{5}{|c|}{ Reliability } \\
\hline $\begin{array}{l}\text { H5. Fulfilling promises to } \\
\text { provide educational services } \\
\text { in a pandemic }\end{array}$ & 6,45 & 5,60 & $-0,85$ & 5,7 \\
\hline $\begin{array}{l}\text { H6. Providing quality } \\
\text { educational services }\end{array}$ & 6,37 & 5,13 & $-1,24$ & 6,92 \\
\hline $\begin{array}{l}\text { H7. Provision of bases of } \\
\text { practices, cooperation with } \\
\text { employers }\end{array}$ & 6,65 & 4,25 & $-2,40$ & 6,23 \\
\hline H8. Employment guarantee & 6,05 & 3,67 & $-2,38$ & 5,87 \\
\hline \multicolumn{5}{|c|}{ Responsiveness } \\
\hline $\begin{array}{l}\text { R9. Rapid response of the } \\
\text { university administration to } \\
\text { student requests }\end{array}$ & 6,41 & 4,53 & $-1,88$ & 6,12 \\
\hline $\begin{array}{l}\text { R10. Trust and } \\
\text { understanding on the part of } \\
\text { the teaching staff }\end{array}$ & 6,76 & 4,15 & $-2,61$ & 6,93 \\
\hline $\begin{array}{l}\text { R11. Willingness to help } \\
\text { students in any situation }\end{array}$ & 6,32 & 4,33 & $-1,99$ & 7,00 \\
\hline \multicolumn{5}{|c|}{ Assurance } \\
\hline $\begin{array}{l}\text { A12. High reputation of the } \\
\text { university }\end{array}$ & 6,20 & 5,27 & $-0,93$ & 7,00 \\
\hline $\begin{array}{l}\text { A13. Availability of } \\
\text { scientific schools }\end{array}$ & 5,48 & 4,32 & $-1,16$ & 5,03 \\
\hline $\begin{array}{l}\text { A14. Discipline and courtesy } \\
\text { of employees, respect for } \\
\text { students }\end{array}$ & 6,86 & 5,27 & $-1,59$ & 7,00 \\
\hline
\end{tabular}


Holovan, O., Oliynyk, O. and Markova, S. (2021), “Application of modern methods of service quality assessment for diagnostics of higher education institution corporate culture", Management and entrepreneurship: trends of development, 1(15), pp. 65-79. Available at: https://doi.org/10.26661/2522-1566/2021-1/15-04

Table continuation

\begin{tabular}{|l|c|c|c|c|}
\hline \multicolumn{1}{|c|}{1} & 2 & 3 & 4 & 5 \\
\hline \multicolumn{3}{|c|}{ Empathy } \\
\hline $\begin{array}{l}\text { E15. Individual approach to } \\
\text { each student in solving his } \\
\text { problems with academic debt } \\
\text { or monthly tuition fees, etc. }\end{array}$ & 6,28 & 5,16 & $-1,12$ & 6,84 \\
\hline $\begin{array}{l}\text { E16. Focus on the needs of } \\
\text { students }\end{array}$ & 6,35 & 5,56 & $-0,79$ & 6,42 \\
\hline $\begin{array}{l}\text { E17. Convenient study } \\
\text { schedule for students }\end{array}$ & 6,06 & 6,48 & 0,42 & 6,78 \\
\hline
\end{tabular}

\section{Source: Own compilation.}

Acceptable results of the procedure of customer satisfaction assessment according to the SERVQUAL method are considered to be the values of quality coefficients $Q_{g_{k}}>-1$. From Table 4 it can be seen that 5 of the 17 criteria, namely criteria T1, H5, A12, E16 and E17, satisfy this condition.

The largest gap between the expected and perceived educational services quality is observed for the criteria T4 (free Wi-Fi at the university), H7 (provision of practice bases, cooperation with employers), H8 (employment guarantee) and R10 (trust and understanding of the teaching staff). composition). It should be noted that these service quality criteria are important for students because they have received a high weight. A low score on these criteria for the quality of students' education at the university reveals the existing problems associated with the available resources of educational activities, namely material-technical, human and social potential.

Based on the results of the diagnosis of the corporate culture state, the administration of higher education institutions need to pay additional attention to the development of high academic culture of employees. As can be seen from Table 4, all the criteria included in the quality indicator "Responsiveness ", students consider important in the study process, but their perceived quality was quite low. Among the reasons are the lack of readiness of some university departments staff to solve quickly students' problems, as well as lack of understanding on the part of some university professors of the need to adapt methods and approaches to teaching materials according to time; insufficient level of introduction of dual education in the institution, due to which students are forced to combine the studying process with the acquisition of practical skills in the workplace without the issuance of appropriate permits, etc.

Along with the criteria included in the quality indicator "Responsiveness", students noted the importance of the following criteria: T2 (excellent interior and equipment of classrooms); T3 (modern computer classes and multimedia classrooms); T4 (free Wi-Fi at the university); H6 (providing quality educational services); A12 (high reputation of the university), A14 (discipline and courtesy of employees, respect for students); E15 (individual approach to each student in solving his problems with academic debt or monthly tuition fees) and E17 (convenient study schedule for students).

In Table 5 the average assessments of educational services expectations and perceptions are presented. 
Average assessments of educational services expectations and perceptions

\begin{tabular}{|c|c|c|}
\hline Quality indicator & $\begin{array}{c}\text { The average level of quality } \\
\text { expectation, } E_{k}\end{array}$ & $\begin{array}{c}\text { The average level of quality } \\
\text { perception, } P_{k}\end{array}$ \\
\hline 1. Tangibles & 6,61 & 5,20 \\
\hline 2. Reliability & 6,38 & 4,66 \\
\hline 3. Responsiveness & 6,50 & 4,34 \\
\hline 4. Assurance & 6,18 & 4,95 \\
\hline 5. Empathy & 6,23 & 5,73 \\
\hline Average score for all parameters & $E=6,38$ & $P=4,98$ \\
\hline
\end{tabular}

Source: Own compilation.

Education quality coefficients relative to expectations and to the ideal have been calculated by formulas (5) - (6).

The education quality coefficient relative to expectations is equal to

$Q_{1}=(6,38-4,98) / 6,38 * 100 \%=21,94 \%$.

The education quality coefficient relative to the ideal is equal to

$Q_{2}=(7-4,98) / 7 * 100 \%=28,86 \%$.

The coefficients show that the deviation of the average level of the education quality perception in the higher education institution in relation to the expected and ideal levels is more than $20 \%$.

\section{CONCLUSION}

Thus, the application of SERVQUAL method to diagnose the level of higher education institution corporate culture has revealed existing problems and appropriate areas for improvement. Among the main problems should be noted the lack of free and quality access to $\mathrm{Wi}-\mathrm{Fi}$ at the university; provision of practice bases and insufficient level of cooperation with potential employers to provide opportunities for further employment after graduation; understanding of the problems and difficulties faced by students during their studies by the teaching staff.

Dialogue with students is an important and, at the same time, complex component of the process of forming the university corporate culture. The importance of the student community corporate culture of the higher education institution is that it allows without pressure from the administration to choose the most effective models of student behavior, promotes the development of their activity and creative abilities. The university corporate culture ensures the unity of students on the basis of common values, which helps maintain a high reputation of the university, maximum motivation of students by creating a favorable psychological climate, moral satisfaction and opportunities for self-development and self-realization.

In this regard, the work of deans and curators of academic groups is important in the direction 
Holovan, O., Oliynyk, O. and Markova, S. (2021), “Application of modern methods of service quality assessment for diagnostics of higher education institution corporate culture", Management and entrepreneurship: trends of development, 1(15), pp. 65-79. Available at: https://doi.org/10.26661/2522-1566/2021-1/15-04

of acquainting students with the norms and values of the university, their rapid adaptation to living conditions, traditions of the institution; prevention of possible negative phenomena in student groups, which are caused either by interpersonal relations or by ethnic, religious reasons.

As measures that will promote the establishment and improvement of relations between students of the faculty, students and teachers, as well as aimed at the formation and development of corporate culture in higher education, we can offer the following:

- holding competitions between departments, teachers and students to determine the best curator of the year, the best lecturer of the year, a teacher with the best sense of humor, a leader among students in success, etc.;

- organization of joint cultural and educational events for students and teachers of the faculty: quests, trainings, tourist trips, etc.;

- development of financial stimulation programs of students research and creative activity.

Thus, the adapted SERVQUAL method for assessing the service quality, used to diagnose the higher education institution corporate culture state, allowed to identify existing problems and suggest ways to improve the elements of higher education institution corporate culture.

\section{REFERENCES}

Bazyliuk, A.V. and Khomenko, I.O. (2013), "SERVQUAL method of evaluating the quality of passengers' transportation service in the city", Project management, systems analysis and logistics. Technical series, vol. 12, pp. 219-230. Available at: http://publications.ntu.edu.ua/upravl_progect/2013_12_econom/005.pdf（Accessed 11 January 2021), (in Ukrainian).

Blokhina, I. O. (2012), "Professional training of specialists in the management of educational institutions as a psychological and pedagogical problem", Visnyk Chernihivs'koho natsional'noho pedahohichnoho universytetu imeni T. H. Shevchenka. Pedahohichni nauky, 1(104), pp. 24-27, (in Ukrainian).

Cameron, K. S. and Quinn, R. E. (2011), Diagnosing and Changing Organizational Culture: Based on the Competing Values Framework, 3rd Edition, Jossey-Bass, San Francisco, USA.

Dem'ianenko, Yu. V. (2011), "The model estimates level of social capital of service enterprises", Visnyk Zaporiz'koho natsional'noho universytetu. Ekonomichni nauky, vol. 9. pp. 102-108. Available at: https://web.znu.edu.ua/herald/issues/2011/eco_2011_1/2011_1/102-108.pdf (Accessed 11 January 2021), (in Ukrainian).

Hnezdilova, K. M. (2013), Korporatyvna kul'tura vykladacha vyschoi shkoly [Corporate culture high school output], ChNU imeni Bohdana Khmel'nyts'koho, Cherkasy, Ukraine, (in Ukrainian).

Holovan', O. O., Olijnyk, O. M., Markova, S. V. and Korniienko, A. I. (2016), "Adaptation of the mechanism of customer loyalty assessment in the context of ensuring the market position of the enterprise". Naukovi pratsi Natsional'noho universytetu kharchovykh tekhnolohij, 22(5), pp. 76-84. Available at: http://sw.nuft.edu.ua/Archiv/2016/swnuft_22_5.pdf (Accessed 11 January 2021), (in Ukrainian).

Karamushka, L. M. (2004), Psykholohiia osvitn'oho menedzhmentu [Psychology of educational management], Lybid', Kyiv, Ukraine, (in Ukrainian).

Karamushka, L. M. and Ischuk, O. V. (2015), Psykholohiia orhanizatsijnoi kul'tury vyschoho navchal'noho zakladu (u konteksti stanovlennia profesijnoi identychnosti studentiv) [Psychology of organizational culture of higher education (in the context of the formation of professional identity of students)], Kruhozir, Kyiv, Zaporizhzhia, Ukraine, (in Ukrainian).

Kojcheva, T. I. (2014), "Experimental Study of the Assessment of Organizational Culture of Pedagogical University by Doctors in Philosophy", Academic Bulletin of Donbas, 1(25). Available at: http://nvd.luguniv.edu.ua/archiv/NN25/8.pdf (Accessed 11 January 2021), (in 
Ukrainian).

Kostrubs'ka, A.F. and Koval'chuk, V. S. (2014), "Marketing assessment of the quality of banking services based on the SERVQUAL methodology", Visnyk Khmel'nyts'koho natsional'noho universytetu. Ekonomichni nauky, 5(2), pp. 76-78. Available at: http://elar.khnu.km.ua/jspui/bitstream/123456789/4010/1/Vchnu_ekon_2014_5\%282\%29_1 9.pdf (Accessed 11 January 2021), (in Ukrainian).

Kubko, V. (2014), "Model of formation of corporate culture of a modern higher educational institution of Ukraine", Visnyk Knyzhkovoi palaty, vol. 8, pp. 40-43, (in Ukrainian).

Lohua, R. A. (2012), "Improving the methodology for assessing customer satisfactionn", Vestnyk Samarskoho hosudarstvennoho unyversyteta, vol. 1, pp. 224-227, (in Russian).

Nakonechna, N. V. (2020), "Analysis of the results of the study of the psychological conditions for the development of corporate culture of a private higher education institution", Pravnychyj visnyk Universytetu «KROK», Issue 34. pp. 114-124, (in Ukrainian).

Novatorov, V.E. and Novytskaia, V.D. (2012), "Modification and empirical verification of the SERVQUAL service quality measurement methodology as applied to banking services", Marketynh $v$ sfere fynansovykh y strakhovykh usluh, vol. 1, pp. 22-32, (in Russian).

Okhota, V. I. and Brych, V. Ya. (2020), "Quality indices of the services (products) of the tourist industry (methodical and empirical aspect)", Ekonomika ta derzhava, vol.4, pp. 68-73. DOI: 10.32702/2306-6806.2020.4.68 (in Ukrainian).

Parasuraman, A., Zeithaml, V.A. and Berry, L.L. (1985), “A Conceptual Model of Service Quality and Its Implications for Future Research", Journal of Marketing, 49(4), p.41. Available at: http://dx.doi.org/10.2307/1251430.

Stadnik, V.H. (2015), "Using Servqual method for assessing the quality of transport-forwarding company", Naukovyj visnyk Khersons'koho derzhavnoho universytetu, 12(3), pp. 79-83, (in Ukrainian).

Toporova, P. K. (2015), "Application of the SERVQUAL methodology in relation to banking services (on the example of the West Ural Bank of Sberbank of Russia)". Available at: http://sibac.info/studconf/econom/xix/37823 (Accessed 11 January 2021), (in Russian).

Yvashkova, N.Y. (2012), "Expanding the analytical capabilities of the service quality assessment methodology SERVQUAL", Bulletin of the Plekhanov Russian University of Economics, vol.8, pp.80-87. Available at: https://rus.neicon.ru/xmlui/handle/123456789/7071 (Accessed 11 January 2021), (in Russian).

Zavats'ka, N. Ye. and Mitichkina, O. O. (2013) Upravlins'kyj protses ta formuvannia orhanizatsijnoi kul'tury $u$ vyschij shkoli: sotsial'no-psykholohichnyj aspekt [Management process and the formation of organizational culture in higher education: socio-psychological aspect], Knowledge, Luhansk, Ukraine, (in Ukrainian).

\section{ЗАСТОСУВАННЯ СУЧАСНИХ МЕТОДИК ОЦІНЮВАННЯ ЯКОСТІ ОБСЛУГОВУВАННЯ ДЛЯ ДІАГНОСТИКИ СТАНУ КОРПОРАТИВНОЇ КУЛЬТУРИ ЗАКЛАДУ ВИЩОЇ ОСВІТИ}

\section{Головань Ольга} Олексіӥвна

Запорізький національний університет

Запоріжжя, Україна

\author{
Олійник Олександр \\ Миколайович \\ Запорізький національний \\ університет \\ Запоріжжя, Україна
}

\author{
Маркова Світлана \\ Вікторівна \\ Запорізький національний \\ університет \\ Запоріжжя, Україна
}

Сфера освіти - один із драйверів розвитку вітчизняної економіки. Ї̈̈ розвиток неможливий без формування стійкої адаптивної організаційної культури закладів освіти. Для формування корпоративної культури закладу вищої освіти необхідно провести діагностику 
Holovan, O., Oliynyk, O. and Markova, S. (2021), “Application of modern methods of service quality assessment for diagnostics of higher education institution corporate culture", Management and entrepreneurship: trends of development, 1(15), pp. 65-79. Available at: https://doi.org/10.26661/2522-1566/2021-1/15-04

його поточного стану. Метою дослідження є адаптація сучасної методики оцінки якості послуг SERVQUAL для діагностики стану корпоративної культури закладу вищої освіти. Методологія: В ході дослідження були вивчені очікування студентів та їх сприйняття якості одержуваних освітніх послуг за показниками адаптованої методики SERVQUAL. Застосування методу SERVQUAL для діагностики рівня корпоративної культури закладу вищої освіти виявило існуючі проблеми та відповідні напрямки для поліпшення. Результати дослідження показують, що серед основних проблем - відсутність безкоштовного і якісного доступу до Wi-Fi в університеті; бази практики i недостатній рівень співпраці 3 потенційними роботодавцями для забезпечення можливості подальшого працевлаштування після закінчення закладу вищої освіти; розуміння проблем і труднощів, з якими стикаються студенти під час навчання, педагогічним колективом. Як заходи щодо підвищення корпоративної культури закладу вищої освіти запропоновано: проведення різних конкурсів між кафедрами, викладачами та студентами; організація спільних культурно-просвітницьких заходів для студентів та викладачів факультету; розробка програм фінансового стимулювання наукової та творчої діяльності студентів.

Ключові слова: освітні послуги, корпоративна культура, заклад вищої освіти, якість послуг, діагностика якості.

\section{ПРИМЕНЕНИЕ СОВРЕМЕННЫХ МЕТОДОВ ОЦЕНКИ КАЧЕСТВА УСЛУГ ДЛЯ ДИАГНОСТИКИ КОРПОРАТИВНОЙ КУЛЬТУРЫ УЧРЕЖДЕНИЯ ВЫСШЕГО ОБРАЗОВАНИЯ}

\section{Головань Ольга}

Алексеевна

Запорожский наџиональный университет

Запорожье, Украина

\author{
Олейник Александр \\ Николаевич \\ Запорожский наџиональный \\ университет \\ Запорожье, Украина
}

\author{
Маркова Светлана \\ Викторовна \\ Запорожский наџиональный \\ университет \\ Запорожье, Украина
}

Сфера образования - один из драйверов развития отечественной экономики. Ее развитие невозможно без формирования устойчивой адаптивной организационной культуры образовательных учреждений. Для формирования корпоративной культуры вуза необходимо провести диагностику ее текущего состояния. Целью исследования является адаптация современной методики оценки качества услуг SERVQUAL для диагностики состояния корпоративной культуры вуза. Методология: В ходе исследования были изучены ожидания студентов и их восприятие качества получаемых образовательных услуг по показателям адаптированной методики SERVQUAL. Применение метода SERVQUAL для диагностики уровня корпоративной культуры вуза выявило существующие проблемы и соответствующие направления для улучшения. Результаты исследования показывают, что среди основных проблем - отсутствие бесплатного и качественного доступа к Wi-Fi в университете; базы практики и недостаточный уровень сотрудничества с потенциальными работодателями для обеспечения возможности дальнейшего трудоустройства после окончания вуза; понимание проблем и трудностей, с которыми сталкиваются студенты во время учебы, педагогическим коллективом. В качестве мер по повышению корпоративной культуры вуза предложено: проведение различных конкурсов между кафедрами, преподавателями и студентами; организация совместных культурно-просветительских мероприятий для студентов и преподавателей факультета; разработка программ финансового стимулирования научной и творческой деятельности студентов.

Ключевые слова: образовательные услуги, корпоративная культура, вуз, качество услуг, диагностика качества. 